\title{
The Measurement of Standard Time for Analysis of Output Standards in the E-Commerce Process
}

\author{
Andreas Tri Panudju ${ }^{1 *}$, Umi Marfuah $^{2}$, Mutmainah $^{3}$ \\ ${ }^{I}$ Department of Industrial Engineering, Faculty of Engineering, Bina Bangsa University, JL Raya Serang - Jakarta, KM. 03 No. \\ 1B, Panancangan, Kec. Cipocok Jaya, Kota Serang, Banten, Indonesia \\ ${ }^{2,3}$ Department of Industrial Engineering, Faculty of Engineering, Universitas Muhammadiyah Jakarta, Jl. Cempaka Putih \\ Tengah 27 No.27/10, RT.7/RW.7, Cemp. Putih Tim., Jakarta Pusat, 10510, Indonesia \\ *Corresponding Author
}

\begin{abstract}
Standard time is very basic when the company analyze its operating process. It departs from a standard time that is measured correctly, there will be a lot of analysis produced to determine important decisions. PT. XNZ, which is a logistics service provider company in the form of warehouse and distribution, has one business partner who applies an ecommerce system in selling its products. The main process carried out by PT.XNZ in providing services to business partners who implement the e-commerce system is the process in the form of product packaging according to orders placed by end customers through online. One of the obstacles faced by PT XNZ at this time is that the exact standard time for each work station is not yet known, so the analysis related to output standard, worker productivity, and realistic operational targets is potentially unrealistic. This research conducted at PT XNZ in determining the standard time for the outbound e-commerce process. The analysis obtained in the outbound e-commerce process shows the conclusion that the packing workstation which has a standard time of 46.7 seconds / box is the bottle neck of the entire outbound process. The current output standard is 76.8 boxes / hour. So that this can become the company's attention to determine the focus of improvements in order to improve service to business partners.
\end{abstract}

Keywords: e-commerce, logistics service, output standard, standard time, the measurement.

\section{INTRODUCTION}

$\mathrm{I}$ $\mathrm{n}$ the development of digitalization in the current era, it has triggered companies to compete fiercely by utilizing the use of technology. One of them is competition in business using e-commerce. Business actors who implement e-commerce can benefit from easily accessing global markets, more accelerated product promotions, building brands, getting closer to customers, and building communication with customers [1]. With the pattern of Indonesian people's activities that are very closely related to the internet, ecommerce is the right choice for business people to win in the competition [2].

PT XNZ, which is a logistics service provider in the form of warehouse and distribution, has one of its business partners who applies an e-commerce system in selling its products. The main process carried out by PT.XNZ in providing services to business partners who implement the e-commerce system is the outbound process in the form of product packaging according to orders placed by end customers online. one of the biggest challenges faced by PT. XNZ is the exact standard of time and capacity at each work station is not known.

The current condition is that the average end-customer demand with an e-commerce system is 800 orders or boxes per day, and in certain conditions such as national online shopping days or promotions, the demand can reach 1,200 to 1,500 orders per day. Departing from this phenomenon, PT. XNZ needs to carry out a more in-depth analysis of the balance of trajectories in the packaging process to determine productivity and prepare alternative solutions if demand spikes at certain times.

An organization that integrates e-commerce or e-business has changed the business flow within an organization itself, and with customers, as well as with shipping and warehousing business partners [3]. However, e-commerce in the shipping and warehousing business brings several advantages, including a faster processing performance, lower costs, and a great time [4], [5]. In addition to being an advantage, of course, e-commerce is also a challenge for warehousing business partners to be better prepared to face it, and the study of processing time is the basis for various planning implementation strategies to be implemented [6].

Standard time is a rational time needed for a worker to complete his task in the work system[7]. Standard time is definitively expressed as the time needed by a worker who has an average level of ability to complete a job [8]. The first step to find out the standard time, it is necessary to measure the working time. The results of this work time measurement need to be carried out in advance of several tests. The tests carried out were uniformity tests and data adequacy tests [8].

\section{METHOD}

The research method is carried out in several stages, including [9]:

a. Measurement of working time

Measurements are made using a stop watch for each admin work station operator, forming box, picking summary, picking order, checking, and packing. 
b. Testing data

Before the data is processed, the data from the observations are tested, both for data uniformity and data adequacy

c. Adjustment factor and allowance factor

Indicators of adjustment factors include: skills, effort, working conditions, and consistency. Meanwhile, indicators of allowance include:

- Exertion

- Work attitude

- Work movement

- Eye fatigue

- Operating temperature conditions

- The state of the atmosphere

- Good environmental conditions

- Personal needs

This adjustment factor and allowance factor will be added to the average processing time.

\section{d. Standard time calculation [3]}

Calculation of standard time is data processing that is carried out by calculating the cycle time average cycle stage. Then the cycle time is added with an adjustment factor, so that the result of the addition is called normal time. Then the final stage of normal time will be added with the allowance factor to obtain the standard time.

e. Calculation of the average standard operator time

To see the workload balance in each work station, then the standard time that has been obtained is averaged based on the number of operators available at each work station.

\section{f. Output standard calculation}

The final stage is to measure the ability or standard capacity of each work station in current conditions.

The data uniformity test is obtained by the following calculations:

- Group data into subgroups

- Calculate the average price of the sub-groups

$$
X=\frac{\sum X n}{n}
$$

- Calculate the average price of the subgroup average prices

$$
\bar{X}=\frac{\sum X_{i}}{n}
$$

- Calculates the real standard deviation

$$
\sigma=\sqrt{\frac{\sum\left(X_{i}-\bar{X}\right)^{2}}{N-1}}
$$

- Calculates the standard deviation of the subgroup mean price

$$
\sigma x=\frac{\sigma}{\sqrt{n}}
$$

- Calculating upper control limits and lower control limits for data uniformity tests.

$$
\begin{aligned}
& U C L=\bar{X}+3 \sigma x \\
& L C L=\bar{X}-3 \sigma x
\end{aligned}
$$

If the subgroup mean is within the control boundary, then the data is said to be uniform. while the data sufficiency test can be calculated using the following formula:

$$
N^{\prime}=\left[\frac{Z / S \sqrt{N\left(\sum X_{i}{ }^{2}\right)-\left(\sum X_{i}\right)^{2}}}{\sum X_{i}}\right]^{2}
$$

Formula description:

$$
\begin{aligned}
& X i=\text { completion time measured at the } \mathrm{i} \\
& \text { observation. } \\
& \bar{X} \quad=\text { the average of the subgroup average } \\
& \text { prices } \\
& N \quad=\text { the amount of measurement data taken } \\
& N^{\prime} \quad=\text { the amount of data required } \\
& Z \quad=\text { confidence level based on normal curve } \\
& \text { emission, } \\
& S \quad=\text { level of accuracy, }
\end{aligned}
$$

if the value of $\mathrm{N}$ is greater than the value of $\mathrm{N}$ ', then the data is said to be sufficient and suitable for further use for the calculation of standard time. To get the standard time, there are a number of steps that must be followed [10]:

1. Calculate the average time (Ws) : $W s=\frac{\sum X_{i}}{N}$

2. Calculate the adjustment factor $(\mathrm{P}): \mathrm{P}=1+\mathrm{p}$

3. Calculating normal time $(\mathrm{Wn}): \mathrm{Wn}=\mathrm{Ws} \times \mathrm{P}$

4. Calculate the allowance factor $=\mathrm{k}$

5. Calculate the standard time $(\mathrm{Wb}): \mathrm{Wb}=\mathrm{Wn} \times(1+$ $\mathrm{k}$ )

Line balancing is a matter of assigning operators to work stations along the process line in such a way that the assignment or assignment of workloads is optimal and reasonable. The focus of line balancing is the standard time 
and workload distribution for each work station [4].

The output standard for each work station can be found if the standard time has been obtained. To calculate the output standard, calculations can be used as follows [7] :

Output Standard =

$$
\begin{gathered}
\text { Standard Output }=\frac{1}{\text { Standard Time }} \\
\text { III. RESULT AND DISCUSSION }
\end{gathered}
$$

The outbound process for e-commerce products carried out by PT. XNZ includes:

\begin{tabular}{|c|c|c|c|}
\hline No & $\begin{array}{l}\text { Work } \\
\text { Station }\end{array}$ & Work Steps & $\begin{array}{l}\text { Number } \\
\text { of } \\
\text { Operators }\end{array}$ \\
\hline 1 & $\begin{array}{l}\text { Preparation } \\
\text { Picklist by } \\
\text { admin }\end{array}$ & $\begin{array}{l}\text { - Admin receives } \\
\text { summary order data that is } \\
\text { integrated in the WMS } \\
\text { Admin processes orders } \\
\text { and describes them into a } \\
\text { picklist summary (done every } \\
09.00 \text { and } 19.00 \text { ) } \\
\text { summary Admin prints a picklist } \\
\text { - Provide a picklist } \\
\text { summary to the forklift operator } \\
\text { summary orders received to be } \\
\text { described into the picklist order } \\
\text { and delivery documents for each } \\
\text { order Admin prints the order } \\
\text { picklist and travel documents } \\
\text { picklist order and a pass to the } \\
\text { picker }\end{array}$ & 1 \\
\hline 2 & $\begin{array}{l}\text { Forming } \\
\text { Box } \\
\text { packing }\end{array}$ & $\begin{array}{l}\text { Picker prepares the } \\
\text { needed materials to support the } \\
\text { packing process, including: box } \\
\text { packing, tape, plastic wrapping. } \\
\text { put them in the packing area }\end{array}$ & 1 \\
\hline 3 & $\begin{array}{l}\text { Picking } \\
\text { Summary }\end{array}$ & $\begin{array}{l}\text { - Forklift operators and a } \\
\text { helper carry out the product } \\
\text { picking process at the location } \\
\text { stated in the picklist summary } \\
\text { - Forklift and helper } \\
\text { operators ensure that the } \\
\text { products picked up are in } \\
\text { accordance with the picklist } \\
\text { summary, including: picking } \\
\text { location, SKU number, product } \\
\text { quantity and batch number. } \\
\text { placed in the shelving area, } \\
\text { then identify the location } \\
\text { according to the location stated } \\
\text { in the picklist summary }\end{array}$ & 2 \\
\hline 4 & $\begin{array}{l}\text { Picking } \\
\text { Order }\end{array}$ & $\begin{array}{l}\text { Picker brings the } \\
\text { picklist order and box that has } \\
\text { been formed to the shelving } \\
\text { area } \\
\text { picking process in the shelving }\end{array}$ & 4 \\
\hline
\end{tabular}

Table 1. Description of Outbound Process Work Steps

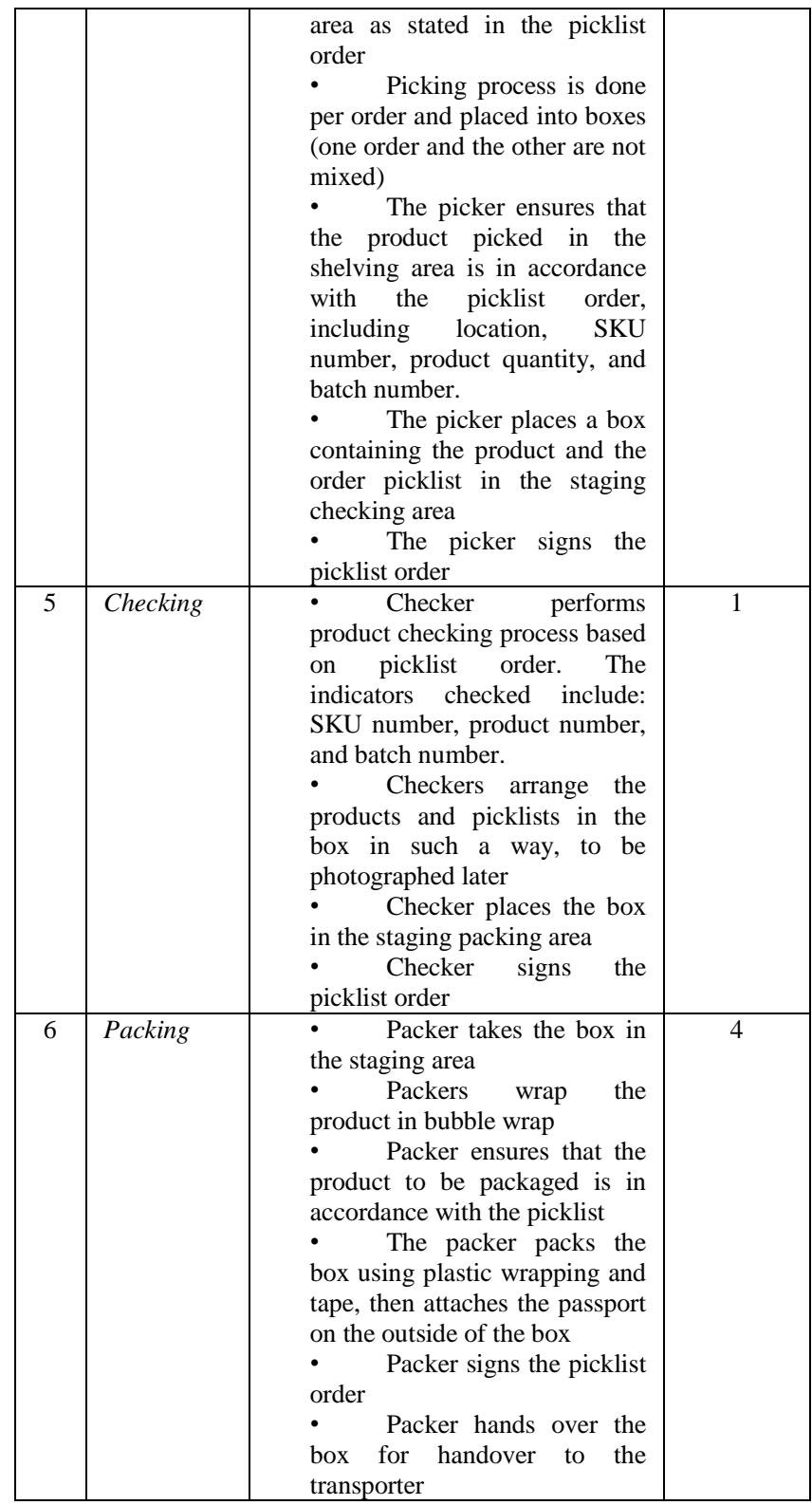

Below is a precedence diagram of the above process steps:

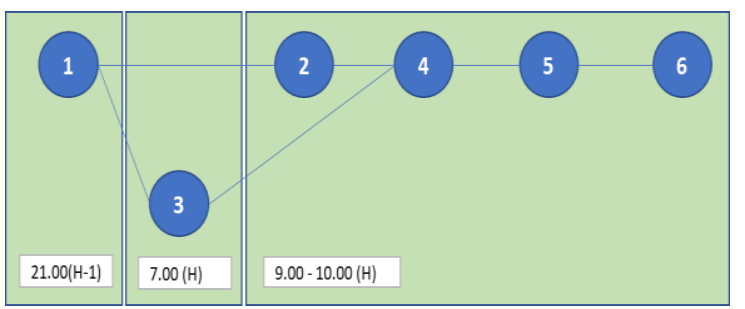

Figure 1. The precedence diagram for the outbound e-commerce process of PT. XNZ

\section{Working Time Measurement and Test Data}

The results of time measurements carried out at each work station using a stop watch are then processed to determine the standard time. Below is an example of the results of measuring work time and test data for a packing workstation. 


\section{Uniformity Test Data}

The data from the time measurement of the packing workstation that has been entered into the subgroup can be seen in the table below:

Table 2. Subgroup Time Measurement of Packing Workstation

\begin{tabular}{|c|cccc|c|}
\hline Sub & \multicolumn{3}{|c|}{ Time Measurement Data } & Average \\
\hline 1 & 158 & 160 & 160 & 162 & 160 \\
\hline 2 & 154 & 152 & 150 & 168 & 156 \\
\hline 3 & 160 & 158 & 156 & 154 & 157 \\
\hline 4 & 158 & 154 & 158 & 160 & 157.5 \\
\hline 5 & 160 & 156 & 158 & 159 & 158.25 \\
\hline & \multicolumn{4}{|c|}{ Subgroup Average } & 157.75 \\
\hline
\end{tabular}

From the table above it can be seen that the subgroup average price is 175.75 . Next is to calculate the subgroup standard deviation with the following calculations:

$$
\begin{aligned}
\sigma & =\sqrt{\frac{\sum(291.75)^{2}}{20-1}}=3.92 \\
\sigma x & =\frac{3.92}{\sqrt{4}}=1.95
\end{aligned}
$$

From the results of these calculations, it is known that the standard deviation for the subgroup mean is 1.95 . then the results of the subgroup average standard deviation are used to measure the upper and lower limits, with the following formula:

$$
\begin{gathered}
\mathrm{UCL}=\overline{\mathrm{X}}+3 \sigma \mathrm{x} \\
\mathrm{UCL}=157.75+3(1.95)=163.6 \\
\mathrm{LCL}=\overline{\mathrm{X}}-3 \sigma \mathrm{x} \\
\mathrm{LCL}=157.75-3(1.95)=151.8
\end{gathered}
$$

Graph visualization to see whether the subgroup mean value is within the upper control limit and the lower control limit, can be seen in the graph below:

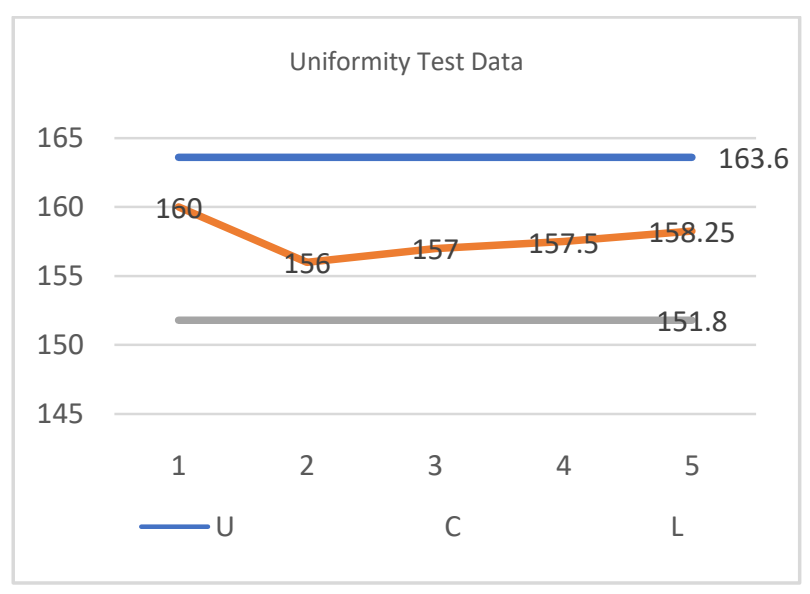

Figure 2. Graph of Subgroup Uniformity Test

From the graph above it can be seen that all subgroup mean values are within the control limit, which means that the data is uniform or in a normal distribution.

\section{Adequacy Data Test}

After the data is declared uniform, the next step is to measure the data adequacy test. Below is an example of calculating the data adequacy test performed for a packing workstation:

$$
\begin{aligned}
& N^{\prime}=\left[\frac{Z / S \sqrt{N\left(\sum X_{i}^{2}\right)-\left(\sum X_{i}\right)^{2}}}{\sum X_{i}}\right]^{2} \\
& N^{\prime}=\left[\frac{1.65 / 0.1 \sqrt{20(497.993)-(3.155)^{2}}}{3.155}\right]^{2}
\end{aligned}
$$

$=0.15$

From the results of this calculation, it can be seen that $\mathrm{N}>\mathrm{N}$ 'or 20>0.15, which states that the data for the packing work

\begin{tabular}{|c|c|c|c|}
\hline Skill & : Good & $=\mathrm{C} 2$ & $=0,03$ \\
\hline Effort & : Good & $=\mathrm{C} 2$ & $=0,02$ \\
\hline Work Condition & : Good & $=\mathrm{C}$ & $=0,02$ \\
\hline Consistency & : Good & $=\mathrm{C}$ & $=0,01+$ \\
\hline Total & & & $=0,08$ \\
\hline
\end{tabular}
station taken is sufficient to be used as analysis data. Likewise for data on other processes, after the calculation of the data sufficiency test was carried out, it was known that the data on all work stations was declared sufficient.

\section{Analysis of Adjustment Factors and Allowance Factors}

The following is an example of the results of observations of adjustment factors made at the packing workstation:

So $\mathrm{P}=(1+0,08)$ or $\mathrm{p}=1,08$

By knowing the adjustment factor, the normal time for the packing station can be calculated using the following formula:

$$
\begin{aligned}
\text { Wn } & =\text { Ws } \times \text { P } \\
& =157.75 \times 1,08=170.37 \text { second } .
\end{aligned}
$$

The obtained normal time must be added with the allowance factor to obtain the standard time. The observation results of the allowance factor for the packing station can be seen in the following table:

Table 3. Workstation Packing Allowance Factors

\begin{tabular}{|l|c|c|}
\hline Allowance Factors & Reference & $\begin{array}{c}\text { Measurement } \\
\text { results }\end{array}$ \\
\hline 1. Allowance to reduce of fatigue \\
\hline $\begin{array}{l}\text { A. Power be used } \\
\text { (negligible) }\end{array}$ & $0,0-6,0 \%$ & $2 \%$ \\
\hline $\begin{array}{l}\text { B. Work attitude } \\
\text { (standing on two legs) }\end{array}$ & $1,0-2.5 \%$ & $1 \%$ \\
\hline C. Work attitude & 0 & $0 \%$ \\
\hline
\end{tabular}




\begin{tabular}{|l|c|c|}
\hline (standing on two legs) & & $3 \%$ \\
\hline $\begin{array}{l}\text { D. Eye fatigue } \\
\text { (intermittent vision) }\end{array}$ & $0-6,0 \%$ & $1 \%$ \\
\hline $\begin{array}{l}\text { E. Workplace } \\
\text { temperature state } \\
\text { (normal) }\end{array}$ & $0-8 \%$ & $1 \%$ \\
\hline $\begin{array}{l}\text { F. The atmosphere } \\
\text { condition (sufficient) }\end{array}$ & $0-5 \%$ & $0 \%$ \\
\hline G. Good Environment for & $0-2,5 \%$ & $2 \%$ \\
\hline $\begin{array}{l}2 . \quad \text { Allowance for } \\
\text { personal needs (L) }\end{array}$ & - & $0 \%$ \\
\hline $\begin{array}{l}3 . \quad \text { Allowance for } \\
\text { resistance is inevitable }\end{array}$ & & $10 \%$ \\
\hline Total & \\
\hline
\end{tabular}

With a allowance factor of $10 \%$, the calculation of the standard time for the packing workstation is as follows:

$$
\begin{aligned}
\mathrm{Wb} & =\mathrm{Wn} \times(1+\mathrm{k}) \\
& =170.37 \times(1+0.10)=187.4 \text { second }
\end{aligned}
$$

The results of calculating the standard time for the whole process can be seen in the following table:

Table 4. Calculation of Standard Time for All Work Stations

\begin{tabular}{|c|c|c|c|c|c|}
\hline $\begin{array}{c}\text { No. } \\
\text { Work } \\
\text { Station }\end{array}$ & $\begin{array}{c}\text { Cycle } \\
\text { Time } \\
\text { (seconds) }\end{array}$ & $\begin{array}{c}\text { Adjustment } \\
\text { Factor }\end{array}$ & $\begin{array}{c}\text { Normal } \\
\text { Time } \\
\text { (Seconds) }\end{array}$ & $\begin{array}{c}\text { Allowance } \\
\text { Factor }\end{array}$ & $\begin{array}{c}\text { Standard } \\
\text { Time } \\
\text { (Seconds) }\end{array}$ \\
\hline 1 & 26 & 1.02 & 26.52 & 1.1 & 29.2 \\
\hline 2 & 25 & 1.03 & 25.75 & 1.08 & 27.8 \\
\hline 3 & 45.5 & 1.08 & 49.14 & 1.2 & 59.0 \\
\hline 4 & 124 & 1.08 & 133.92 & 1.2 & 160.7 \\
\hline 5 & 30 & 1.03 & 30.9 & 1.1 & 34.0 \\
\hline 6 & 157.75 & 1.08 & 170.37 & 1.1 & 187.4 \\
\hline
\end{tabular}

To see the balance of the outbound e-commerce process trajectory, it is necessary to know the average standard time of each operator at each step of the process. This can also be a basis for analysis to see the workload for each operator at each work station. An example of calculating the average standard time for operators for a packing work station, where the standard processing time is 187.4 seconds and the number of operators is 4 people, then the average standard time is 187.4 divided by 4 or 46.9 seconds. The results of the calculation of the average standard time for line balancing for the entire process can be seen in the table below as in the table below:

Table 5. Standard Time for Line Balancing of All Work Stations

\begin{tabular}{|c|c|c|c|}
\hline $\begin{array}{c}\text { No. Work } \\
\text { Station }\end{array}$ & $\begin{array}{c}\text { Standard Time } \\
\text { (Seconds) }\end{array}$ & $\begin{array}{c}\text { Numbers of } \\
\text { Operator }\end{array}$ & $\begin{array}{c}\text { Average of } \\
\text { Standard Time } \\
\text { (Seconds) }\end{array}$ \\
\hline 1 & 29.2 & 1 & 29.2 \\
\hline 2 & 27.8 & 1 & 27.8 \\
\hline 3 & 59.0 & 2 & 29.5 \\
\hline 4 & 160.7 & 4 & 40.2 \\
\hline 5 & 34.0 & 1 & 34.0 \\
\hline 6 & 187.4 & 4 & 46.9 \\
\hline
\end{tabular}

The final step is the calculation of the output standard for each workstation. An example of calculating the output standard for a packing workstation is as follows:

$$
\text { standard output }=\frac{1}{\text { standard time }}
$$

So that the output standard for the packing process is $1 / 46.9$ or 0.02 boxes / second or 76.8 boxes / hour. The following is the result of calculating the capacity standard for all work stations:

Table 6. Output Standards for All Work Stations

\begin{tabular}{|c|c|c|c|}
\hline No. Process & $\begin{array}{c}\text { Average of } \\
\text { Standard Time } \\
\text { (Seconds) }\end{array}$ & $\begin{array}{c}\text { Output } \\
\text { standard (box / } \\
\text { second) }\end{array}$ & $\begin{array}{c}\text { Output standard } \\
\text { (box/hour) }\end{array}$ \\
\hline 1 & 29.2 & 0.03 & 123.4 \\
\hline 2 & 27.8 & 0.04 & 129.4 \\
\hline 3 & 29.5 & 0.03 & 122.1 \\
\hline 4 & 40.2 & 0.02 & 89.6 \\
\hline 5 & 34.0 & 0.03 & 105.9 \\
\hline 6 & 46.9 & 0.02 & 76.8 \\
\hline
\end{tabular}

\section{IV.CONCLUSION}

The standard time obtained for each work station is known that the packing work station has the highest standard time, amounting to 46.7 seconds / box / operator. So that the packing workstation is the bottle neck of the entire work station which can then become a focus for the company to do repairs. From the output standard for all work stations that have been measured, it can be concluded that the output standard packing, which is a bottle neck, is a picture of the output standard for the entire outbound e-commerce process, where the output standard obtained is 76.8 boxes per hour.

\section{ACKNOWLEDGMENT}

This research was supported/partially supported by PT. XNZ. We thank our colleagues from PT. XNZ who provided insight and expertise that greatly assisted the research, although they may not agree with all of the interpretations/conclusions of this paper.

\section{REFERENCES}

[1] S. Maryama, "Penerapan E-Commerce Dalam Meningkatkan Daya Saing Usaha," Liquidity, vol. 2, no. 1, pp. 73-79, 2018, doi: 10.32546/lq.v2i1.132.

[2] M. Pradana, "Klasifikasi Bisnis E-Commerce Di Indonesia," Modus, vol. 27, no. 2, p. 163, 2016, doi: 10.24002/modus.v27i2.554.

[3] L. P. S. Hartanti, "Work Measurement Approach To Determine Standard Time In Assembly Line.," Int. J. Manag. Appl. Sci., 2016.

[4] K. Morshed, N, M. \& Palash, S, "Assembly Line Balancing to Improve Productivity Using Work Sharing Method in Apparel Industry.," Glob. J. Res. Eng. G Ind. Eng., 2014.

[5] N. T. Thomopoulos, Assembly line planning and control. New York: Springer, 2014.

[6] A. C. Shettigar, S. Hamritha, and A. Balakrishna, "Efficiency improvement in the assembly line with the application of assembly 
line balancing method," Int. J. Recent Technol. Eng., vol. 8, no. 2 Special Issue 3, pp. 848-853, 2019, doi: 10.35940/ijrte.B1159.0782S319.

[7] R. P. Lukodono and S. K. Ulfa, "Determination of Standard Time in Packaging Processing Using Stopwatch Time Study To Find Output Standard," J. Eng. Manag. Ind. Syst., vol. 5, no. 2, pp. 87-94, 2018, doi: 10.21776/ub.jemis.2017.005.02.5.

[8] K. . Kulkarni, P. P., Kshire, S.S. and Chandratre, "Productivity
Improvement through Lean Deployment \&Work Study Methods.," Int. J. Res. Eng. Technol., 2014.

[9] W. Pisuchpen, R. and Chansangar, "Modifying Production Line for Productivity Improvement: A Case Study of Vision Lens Factory," Songklanakarin J. Sci. Technol., 2014.

[10] Chandurkar, "Improve Productivity with Help of Industrial Engineering Techniques.," Int. J. Text. Eng. Process, 2015. 